\title{
Correction: Campylobacter jejuni dsb gene expression is regulated by iron in a Fur- dependent manner and by a translational coupling mechanism
}

Anna D Grabowska ${ }^{1,2}$, Michał P Wande ${ }^{3,1}$, Anna M Łasica' ${ }^{1}$, Monika Nesteruk ${ }^{4,1}$, Paula Roszczenko', Agnieszka Wyszyńska ${ }^{1}$, Renata Godlewska ${ }^{1}$ and Elzbieta K Jagusztyn-Krynicka ${ }^{1 *}$

\section{Correction}

After publication of this work [1], it came to our attention that the grant numbers in the Acknowledgements section were incorrect. This work was supported by two grants from Polish Ministry of Science and Higher Education (No. N303 341835 and N401 183 31/3968) and by intramural grant of University of Warsaw (BW 19126).

\begin{abstract}
Author details
'Department of Bacterial Genetics, Institute of Microbiology, University of Warsaw, Miecznikowa 1, 02-096 Warsaw, Poland. ²Department of Molecular Mechanisms of Mycobacterial Infections, Institute of Pharmacology and Structural Biology, 205, route de Narbonne, 31077 Toulouse cedex, France. ${ }^{3}$ Division of Protein and Nucleic Acid Chemistry MRC Laboratory of Molecular Biology, Hills Road, CB2 OQH Cambridge, UK. ${ }^{4}$ Department of Gastroenterology, The Medical Centre of Postgraduate Education, Marymoncka 99/103, 01-813 Warsaw, Poland.
\end{abstract}

Received: 27 March 2012 Accepted: 19 April 2012

Published: 19 April 2012

\section{Reference}

1. Grabowska AD, Wandel M, Lasica AM, Nesteruk M, Roszczenko P, Wyszynska A, Godlewska R, Jagusztyn-Krynicka EK: Campylobacter jejuni dsb gene expression is regulated by iron in a Fur-dependent manner and by a translational coupling mechanism. BMC Microbiol 2011, 11:166.

doi:10.1186/1471-2180-12-58

Cite this article as: Grabowska et al.: Correction: Campylobacter jejuni $d s b$ gene expression is regulated by iron in a Fur-dependent manner and by a translational coupling mechanism. BMC Microbiology 2012 12:58.

\footnotetext{
* Correspondence: kjkryn@biol.uw.edu.pl

'Department of Bacterial Genetics, Institute of Microbiology, University of Warsaw, Miecznikowa 1, 02-096 Warsaw, Poland

Full list of author information is available at the end of the article
}

Submit your next manuscript to BioMed Central and take full advantage of:

- Convenient online submission

- Thorough peer review

- No space constraints or color figure charges

- Immediate publication on acceptance

- Inclusion in PubMed, CAS, Scopus and Google Scholar

- Research which is freely available for redistribution

Submit your manuscript at www.biomedcentral.com/submit
() Biomed Central
C Biomed Central

(C) 2012 Grabowska et al; licensee BioMed Central Ltd. This is an Open Access article distributed under the terms of the Creative Commons Attribution License (http://creativecommons.org/licenses/by/2.0), which permits unrestricted use, distribution, and reproduction in any medium, provided the original work is properly cited. 